\title{
Early Childhood
}

National Cancer Institute

\section{Source}

National Cancer Institute. Early Childhood. NCI Thesaurus. Code C89346.

A human life stage that begins at two years of age and continues until five complete years of age. 